\title{
The Method of Takhrïj Hadîts 'Lâwasiyyata liwâritsin' and Its Implications for the Understanding of the Takhshish al-Qur'an by the Hadìts in Inheritance law
}

\author{
Eti Maryati \\ Pascasarjana UIN Sunan Gunung Djati Bandung \\ Email : etimaryati11@gmail.com
}

\begin{abstract}
The hadith prohibits the will is authentic as the Hadith because of the idhafah of the Prophet SAW, and the Hadith is revealed in thirteen books of the mashâdir al-ashliyyah, and fulfills the element of the Hadìts, an eternal consisting of 136 rawi sanad. Honesty of the Hadiths Prohibition of the Will to the Heirs in terms of the number of rawi including Muthat because narrated by many friends without seeing the quality of the material and raw so that it includes Qath'i al-wurûd and Qath'i dilâlah. Based on the rules of tashhih, if seen from a part of the rawi mate that collapsed, including da'eef and could not rise to hasan so mardud. For sanad who are ghair matruk, the term is hasan lighairihi which appears because there is mutabi and shaheed. Surat al-Baqarah verse 180 regarding the obligation to make a will can be compromised by inheritance verses by seeing it as a provision that each has a different target. The verses on inheritance specialize the provisions of a will that are general in nature and in the inheritance verses of Surah al-Nisa verses 11-12, show some of the afrad (material) testament obligations that are general to those who inherit only. Because there is a problem in understanding the will can be haram, makruh / mubah. In practice in daily life, the will is needed to bring good to the heirs who are likely to share the inheritance with other heirs. A will is an alms intended to draw closer to Allah SWT, it also becomes one of the ways to equalize inheritance for those who do not get inheritance rights while they are close relatives
\end{abstract}

Keywords: Hadits, Inheritance Law, Takhrij

\section{INTRODUCTION}

In Islam, it becomes the ulama's agreement that al-Qur'an is the first source of law that contains the basic principles that are general to Islamic sharia, without details in detail, while Hadits as the second source of law to explain the generality of the Qur'an (Azwar, 2015). Found so many verses of the Koran that indicate that Muslims obey Allah SWT and His Messenger, which means giving appreciation to the Koran and the Hadith, do not rule out one of them (QS. ali-Imran (3): 32, an-Nisa (4): 59, al-Anfal (8): 20, an-Nur (24): 54 and Muhammad (47): 33). Then the Hadiths as the second source of law after the Koran appears as explanatory (bayân) of verses of the Koran that are global, interpreting the mubham, explaining the still mujmal, limiting the absolute (muqayyad), specialize the general ('h) and explain laws that are not explicitly explained by the Koran.

These verses are known as inheritance verses. The provisions in these verses provide clarity regarding the parties entitled to receive a share of the inheritance of the deceased, so that the distribution no longer depends on the will of the owner of the property. Some scholars consider that the provisions in the wills verses have been removed by the provisions in the inheritance verses which came down later (Khalid, 2015). In the book of Bulugh al-Maram there are Hadits which explain that there is no will to heir (Sunarsa, 2018).

"The hadith from Abu Umamah, I heard the Messenger of Allah saying: verily Allah SWT has given rights to everyone who has rights, then there is no will for the testator."

* Copyright (c) 2019 Eti Maryati

This work is licensed under a Creative Commons Attribution-ShareAlike 4.0 International License. 
A will is someone's gift to someone else in the form of goods, debt or benefits (Mudawam, 2012). A will is a message of someone who is still alive so that his / her wealth is given / delivered / handed over to a certain person or to an institution which must be carried out after he or she has died, which does not amount to more than a third of the assets he has left (Dirjen Pembinaan Kelembagaan Agama Islam, 1998).

According to Shafi'i, verily Allah SWT sent down the will and also revealed the inheritance verse. This implies that the will remains in harmony with the inheritance. Some scholars consider that the provisions in the wills verses have been removed by the provisions in the inheritance verses which came down later.

Therefore the Hadith of the Prophet (PBUH) about " Lâ Washiyyata Liwâritsin 'is interesting to conduct an in-depth study both in terms of rawi, sanad and matan, to find out their usefulness in order to obtain a clear understanding of the position of the Hadith, especially in the context of the implications of developing problems in the community.

\section{METHODOLOGY}

The method used in this research is library research, content analysis and Takhrîj method. The library research method is carried out by collecting data contained in literature books, seminar results and other sources related to the problem taken. This research was carried out by examining books and writings relating to the Hadits about lâwasiyyata liwâritsin. Content analysis method is a research method that utilizes a set of procedures to draw a valid conclusion from a document or message carried out objectively and systematically (Sugiyono, 2011).

The takhrij method is a special method used in examining the authenticity and quality of a hadit. The takhrij method means the mention of the Hadits with each of their sanads in the Hadits source book and explaining their dignity according to their needs (Fatki, 2012).

Data analysis is an effort to detail and classify data and an interpretation and criticism is carried out in order to obtain a conclusion from the data under study. The steps in this data analysis include:

1. Analyze all data that has been collected both from the main data source and supporting data sources

2. Grouping all data into units according to the problem under study.

3. Perform validation of grouped data

4. Linking one data with another data

5. Analyzing, interpreting and making conclusions based on data obtained

\section{RESULT AND DISCUSSION}

\section{Implications of Hadîts "Lâ Wasiyyata Liwâritsin" on the Understanding of the Nasakh and Takhsis al-Qur'an by Hadìts in inheritance law.}

Ibn Kathir (d. 774 H.), states that the Surah al-Baqarah verse 180 contains mandatory mandatory wills before the passage of the verses on inheritance. After the revelation of inheritance verses which stipulates the distribution of inheritance in detail, the obligation to carry out will be abolished specifically for parents and close relatives who inherit. Furthermore, he asserted that the inheritance verses do not constitute the overall testamentary law, but only raise a portion of the afrad (material) testamentary obligations of a general nature. Therefore, the inheritance verses only raise the wills law for those who inherit it. 
IJIK, Vol. 9 No. 2: 72-79

The Method Of Takhrīj Hadîts 'Lâwasiyyata Liwâritsin' And Its Implications For The Understanding Of The Takhshish Al-Qur'an By The Hadīts In Inheritance Law

Eti Maryati

Ibn Kathir cites the opinion of al-Razi in his commentary titled al-Kabir, that according to Abu Muslim al-Ashfihani, the verse about the will not be mandatory wills, but still muhkam and interpreted by verses about inheritance, so the meaning is:

"It is obliged upon you something that God has required, namely about the inheritance of both parents and relatives based on His word "God has obliged you to give boys the same as the two daughters".

Al-Razi states that this is the opinion of the majority of mufassir and is popular among the jurists, but according to Ibn Abbas, Hasan, Masruq,

Thawus, Dhahak and others, this verse mansukh to the heirs who inherit, and still muhkam for relatives who do not get the inheritance. Some other scholars are not willing to call it a nasakh because those raised by inheritance verses are only some of the afrad from general will not verses. Therefore, the obligation to keep remains obligatory for those who do not receive inheritance. follows:

Al-Tabariy (d. 310 H.), in his book Jami 'al-Bayan, interprets Surat al-Baqarah verse 180 as

"It is obliged upon you, believers to make a will when one of you is near death while he has khairan, and al-khair means property, to (given to) parents and close relatives who do not receive inheritance, properly (ma'ruf) . It is something that has been permitted by Allah and allowed in the will, as long as it does not exceed one third of the assets and the person who has the will does not do wrong to his heirs. And that is an obligation on the righteous. This has been obliged upon you and Allah has made it a mandatory requirement for those who fear Him, so that they obey Allah and carry it out (Salenda, 2017)"

Al-Tabari explained that the will of the law is mandatory based on lafazh amar (kutiba). If someone fails to make a will, then the will must be issued by his heir. Al-Tabari disagrees that the wills verse has been inherited by the inheritance verse because between the two there is a possibility (ihtimal) to be collected, while between nasikh and mansukh it is impossible to gather in one condition. As for collecting both of these verses the will must be understood only aimed at parents and relatives who did not inherit. Thus, according to al-Tabari each of these verses (about will and inheritance) has a different target. In this case, al-Tabari denies the use of the term nasakh to the will of the will by the inheritance verse and agrees that the compulsory law of the will only applies to alwalidain and al-aqrabun who did not obtain part of the inheritance.

Ibn al- 'Arabi (467H.-543H) (2014) argues to differences in opinions of scholars about Muhkam or its mansukh Surat al-Baqarah verse 180, confirms his opinion that the verse is mansukh, but the law is circumcision (only recommended), based on zhahir Hadîts Ibn Umar which reads:

'For telling us Ali bin Muhammad, for telling us Abdullah bin Numair from Ubaidullah bin Umar from Nafi 'from Ibn Umar, he said; The Prophet sallallaahu 'alaihi wasallam said: "There is no right of a Muslim who stays overnight for two nights and he has something that is inherited, except his will is written on his side."

However, Rashid Rida explained that Surah al-Baqarah verse 180 is muhkam, not mansukh. He interpreted the verse as follows (Amir, Shuriye, \& Daoud, 2013):

"Obligatory to you if one of you is near death means to be obliged to you 0 believers if one of you is overwritten by causes or signs of death, if leaving property means if he has a lot of wealth left for his heirs, testament to parents and good friendship means that it is obligatory upon you in this situation to intend to the parents and close relatives of part of the wealth (lots) in good 
IJIK, Vol. 9 No. 2: 72-79

The Method Of Takhrīj Hadîts 'Lâwasiyyata Liwâritsin' And Its Implications For The Understanding Of The Takhshish Al-Qur'an By The Hadīts In Inheritance Law

Eti Maryati

manner, and is not considered to be denial if the asset is a little based on the sentence al-khairi (a lot of wealth) and does not cause harm to inheritance because many wills testament and do not overestimate that will from one third of the inheritance to parents and other relatives".

1. From the description of several opinions of different scholars, it can be concluded that:

2. The will of the will has been made entirely in accordance with the inheritance verses, therefore there is no longer an obligation to testify, however if it is carried out then the law is circumcision.

3. The will remains valid (muhkam), but it is only intended for a portion of heirs who do not get an inheritance, whether the property is large or small.

4. The will is still valid (muhkam), which is required for people who have only a lot of wealth and is given to some heirs who did not get an inheritance.

Interpreters are more inclined to the third opinion, arguing that:

1. Surah al-Baqarah verse 180 can be compromised with inheritance verses by seeing it as a provision that each has a different target. The verses on inheritance specialize general provisions of a will.

2. In the verses of inheritance QS. al-Nisa '(4): $\{11-12\}$ Allah states: ... min ba' di washiyyatin au dainin .... If the will is removed, then in the inheritance verses of God will not reveal the sentence again.

3. The will must be fulfilled by anyone who has a lot of wealth. The reason is that the sentence khairan means a lot of wealth and the determination of the amount of wealth is very relative and depends on the habits of the community (urf). In addition, other liabilities relating to assets are always associated with a certain amount, such as new zakat which is compulsory if the assets arrive.

The argument about the possibility of carrying out a will is also based on the scholars' consent. Basically, the scholars agree that the act of wills is a shari'ah of Allah SWT and His Messenger. This is based on the verses and hadith above Az-Zuhaili (1998) which puts forward the urgency of carrying out a will, not only for the person who has a will, but also for the recipient of the will and heirs who will be left behind. Thus, in addition to alms as intended to draw closer to Allah SWT, the will also becomes one of the ways to equalize inheritance for those who do not get inheritance rights while they are close relatives.

Furthermore, in the study of interpretation, lafaz kutiba and khairan in surah al Baqarah verse 180 also triggered differences of opinion among ulama. The majority of commentators believe that the lafaz kutiba in surah al-Baqarah verse 180 shows the meaning of obligation. According to alJashshash, the mandatory indications are reinforced again by the phrase "haqqan" ala al-muttaqin ". These compulsory claims are only intended to be given to al-walidain and al-aqrabun who do not obtain inheritance.

But because of some qarinah (indications / instructions), then the obligation must be turned to another meaning. The indications are (Abubakar, 2016).:

1. There are verses on inheritance which have specifically determined the rights and inheritance parts of parents and other relatives. With the existence of these verses, the inheritance obligations to parents and other relatives are no longer relevant because they have been abolished.

2. Hadith saheeh stating that no inheritance should be made (lawashiyyata li waritsin).

3. The historical fact that the Messenger of Allah and his Companions never made a will for members of his relatives. 
IJIK, Vol. 9 No. 2: 72-79

The Method Of Takhrīj Hadîts 'Lâwasiyyata Liwâritsin' And Its Implications For The Understanding Of The Takhshish Al-Qur'an By The Hadīts In Inheritance Law

Eti Maryati

Based on the three qarinah, the jumhur fuqaha 'believes that the above verse can no longer be held in a harfiyah manner. If it is related to the Hadith saheeh la washiyata li waritsin, then the word kutiba in the verse al Baqarah verse 180, no longer means mandatory. On the contrary based on the hadith, jumhur ulama are of the opinion that a will is not valid to the heir. However, according to the Hanafi and Maliki schools, the wills law to heirs is considered valid, on condition that the other heirs are happy. Thus, even though the existence of the hadith has mandated the law of a will to heir, but this does not mean to consecrate his ability. (Az-Zuhaili, 1998).

According to Hanafiyah scholars, as quoted by Abd. al-Rahman al-Jaziry (2003), the word of God in surah al-Baqarah verse 180 has been made based on inheritance verses. Surat al-Baqarah verse 180 only contains temporary legal provisions to provide a will to parents and close relatives before the inheritance verses are revealed. Thus, it can be understood that after the revelation of verses that specifically talk about inheritance, the inheritance obligation to heirs no longer applies. Based on the description above, the jumhur ulama's reasoning about testamentary law can basically be classified into two forms, namely:

1. Ta'abbudi's will is a will that must be done because it is related to obligations that must be (not yet) fulfilled, such as debts that have not yet been fulfilled, zakat that has not been issued or expiation. A will in this form must be done. Thus, the person will sin if he does not do it. But the court or surviving family does not have the right to impose its implementation if it is not spoken.

2. A will that is ikhtiyariyah is a will given to a relative who does not receive inheritance or to another person based on the will of the will. The will in this form can be circumcised, makruh, mubah, or haram.

The debate around nasikh-mansukh is not limited to whether or not this process can occur in the book of Allah. In the end most scholars depart from understanding the verses of al-Qu'an QS.AlBaqarah (2): (106).

In terms of language, there is agreement among scholars regarding the meaning of the word nasakh. Differences that invite pros and cons among scholars occur when they enter the discussion of words

"The verse contained in Surah al-Baqarah verse 106. According to Hasbi Ash-Shiddieqi interprets the word verse with miracles. While other groups interpret the word verse with the verse itself "

Hasbi ash-shiddieqi disagrees with the occurrence of nasakh in the Qur'an by saying, if punished there is a verse that has been condemned in the Qur'an means canceling some of its contents. To cancel that means to establish that in the Qur'an there is something wrong (wrong).

Then, in the view of groups who do not approve of the verses of the Qur'an, the existence of verses that appear to conflict with each other can actually be compromised or combined. For example by way of the regional minister one of the verses that is considered contradictory:

"It has been determined for you, if someone among you breathes out his last breath, if he leaves wealth, in order to make a will for his father and his closest relatives"

This verse is considered null (mansukh) by the support group of nasikh-mansukh in the Qur'anic verse. The inheritance is the heirloom verses (mawaris). However, by the contra groups, this verse is considered not to contradict the verse of the Rose, because there is no contradiction between giving heirlooms and willing about some of the gifts of Allah SWT. If it is still considered mansukh, the heirloom verse is seen as pentakhshih (testamentary verses). Verses of the will according to hasbi, oblige for relatives, while heirlooms exclude relatives who receive heirlooms in general verses. Furthermore according to Hasbi, mother and father do not always take inheritance, mother and 
IJIK, Vol. 9 No. 2: 72-79

The Method Of Takhrīj Hadîts 'Lâwasiyyata Liwâritsin' And Its Implications For The Understanding Of The Takhshish Al-Qur'an By The Hadīts In Inheritance Law

Eti Maryati

father sometimes take heirlooms, sometimes not, because of religious differences, slavery, and murder.

The existence of two interpretive visions of the word verse gives birth to pros and cons regarding the obedience of the verses of the Qur'an. Nasakh for those who deny it is considered as a nightmare and something that is making it up. While for those who support the existence of nasakh means, revoke the enactment of Islamic law 'with the proposition of Islamic law' which comes later is very possible and logical. The determination and revocation of a law is based on the consideration of benefit. According to Shubhi Salih gave an excuse to analogize the turban of the Qur'an to the Prophet gradually. The verses of al-Qur'an are revealed by Allah SWT in accordance with the case, according to the evolving reality and pay attention to the ability of human beings to embrace the message brought by the Qur'an. And according to sayyid Abu al-Qasim al-Khu'I, the bias can be, a law is set for a certain time and that time only Allah knows. If Allah SWT views, the validity period of a law has ended, there is no harm in revoking the law and replacing it with other laws in accordance with the benefit that may only be known to Allah SWT.

In the tradition of Islamic scholars, differences of opinion are not new, let alone considered taboo. There are countless books written by scholars especially compiled to summarize, study, compare, then discuss various different views with their respective arguments.

Discrepancies in the data received regarding the beliefs or deeds of one Hadith. Considering the uneven literature, it is possible for someone to believe that a Hadits is shahîh based on the book available to him, while the data about his devotion has not yet reached him because it is contained in another book (al-Jaziry, 2003).

Difference in starting point in drawing conclusions. That is in matters of religion, there are some who point to the texts of the Qur'an and the Sunnah, while others start from schools, places, organizations, reason, feelings or traditions (al-Jaziry, 2003).

Differences in understanding or perception in understanding texts that have been agreed upon keshahîhan. The contents of al-Qur'an and al-Sunnah are not always qath'i dilâlah, but there is also zhannî which is forbidden. So in drawing conclusions from the texts that zhannî dilâlah allows differences of opinion occur (al-Jaziry, 2003).

Differences in the formulation of Mushthalah Hadits, Ussh Fiqh or other formulations. For example, if there is a conflict between the Qur'an and the Hadith, which should take precedence? Some argue that the Hadiths must take precedence, because no one knows better about the content of the Qur'an except the Prophet SAW. While others argue the Qur'an must take precedence. Another problem is related to the formulation of nâsikh mansûkh, there is no agreement among the ulemas. In understanding the mutasyâbihat texts, some use ta'wîl, others do not use ta'wîl (al-Jaziry, 2003).

The proposition has arrived at him but has been dispatched, but he does not know the proposition that put him off. In cases like this, people who do not know the existence of nasakh are forgiven, because the origin of a problem is the absence of nasakh, until it is known that the argument that abused him.

Hadiths (the argument) has reached him, but he forgot the proposition. It has become sunnatullah, that forgetting is part of our nature as ordinary people. Many people who have memorized the many Hadiths of the Prophet Muhammad, but then he forgot. This is one of the causes of differences of opinion, even though the portion is not too large (al-Jaziry, 2003).

However, it should also be added that despite the mutual respect for differences of opinion, the 'ulama still agreed on the obligation to always hold fast and refer to the Qur'an and the Hadith.

But apart from that all, for us as Muslims, in terms of ibâdah, including the will in it, must try to be based on the arguments that are shahîh. We must also try to avoid the attitude of blind taqlîd, which is taking an opinion without knowing the basis of its reference. 
IJIK, Vol. 9 No. 2: 72-79

The Method Of Takhrīj Hadîts 'Lâwasiyyata Liwâritsin' And Its Implications For The Understanding Of The Takhshish Al-Qur'an By The Hadīts In Inheritance Law

Eti Maryati

Lafaz لاوصية also is 'am in the form of nafi which shows that illegitimate will to heirs. For equality with naskhsis there are three things, among others; First, both provide legal provisions, Naskh gives time limits, while takshi gives material restrictions. Second, both provide restrictions on the enactment of a syariah law provisions. And third, both in the form of the proposition syara '. As for the difference there are five things:

1. The pronunciation 'am after being translated will become vague in scope, because the form is still common. The pronunciation of the proposition which has been validated is no longer valid, so it is clear that the scope has stopped. Example; QS provisions. Al-Mujadalah: 12 is no longer valid because there are new provisions in the QS. Al-Mujadalah: 13.

2. The legal provisions have been excluded from taxation from the beginning, while the legal provisions were abolished, initially intended and enforced for a number of times, but after a change in circumstances prevailed, the legal provisions were enshrined. Examples of takhsis; QS. Al-'Asr, example of mansukh; QS. Al-Ahzab: 52. Which explains the prohibition of the Prophet SAW. It has been forbidden, and has been in effect for some time, but because of frequent battles that cause many friends to die, so many widows are displaced, then the verse that disappears, namely QS. Al-Ahzab: 50.

3. Naskh invalidates the validity of the law entered, while takhsis does not cancel, but only limits its scope, while the legal provisions still apply to those not excluded by restrictions.

4. Nasikh cannot occur except in al-Qur'an and as-Sunnah, while takhsis can occur in al-Qur'an, as-Sunnah, or in other laws outside the two laws.

5. Naskh that the argument of nasikh must come later after the provisions of the first argument apply first, then abolished. While in takhsis, the thesis which mentakhsis (mukhossis) may come together with the thesis which is ditachsis. Example; QS. Al-'Asr, QS. Al-Baqarah: 228 with 237.

\section{CONCLUSION}

Hadìts lâ wasiyyata liwâritsin is marfu 'qawli haqiqi, meaning, these Hadìts are attributed to the Prophet SAW in the form of his saying with explicit signs. Hadits ahad 'aziz is famous, meaning narrated by the number of non-Muthatis narrators, namely two rawiqs in the thabaqah of companions and tabi'in, while in the next thabaqah narrated by three even more narrators. From each of these companions, except 'Amru bin Khârîjah ibn Al Muntafíq, the Hadìts are only narrated by more than one person, while the Hadits who pass through the Anas path, from the first narrator to the last rawi narrator are narrated by only one rawi man. Based on the I'tibar diwan, the Hadits lâ wasiyyata liwâritsin are probably the Hadīts saheeh, hasan, dha'if, even maudhu', matruk or munkar, because the type of the book of mashâdir' ashliyyah is the book of Musnad and Mushannaf. Based on I'tibar syarah, it means that there is Takhshish al-Quran by the Hadith, about inheritance and testament shows that Allah SWT requires the division of warian and that it does not have to abrogate the obligation to make a will because between these verses there is a possibility (ihtimal) to be combined. Allah SWT has revealed verses on inheritance obligations earlier than verses on inheritance. Olh because there is no prohibition to issue a will earlier than inheritance as in Surat alNisa verses 11 and 12 .

Hadìts lâ wasiyyata liwâritsin is to contain the sentence Nafi. That is, the Hadith's words may contain haram to be done. The problem with the difference in understanding between the existence of Takhshish al-Quran by Hadits, is that some scholars consider that the provisions in the wills verses have been removed by the provisions in the warits verses that came down later, actually between the will and inheritance is not contradictory but rather specifies the division. In practice in daily life, the will is needed to bring good to the heirs who are likely to share the inheritance with other heirs. So 
the will is legally recommended. Surat al-Baqarah verse 180 regarding the obligation to make a will can be compromised by inheritance verses by seeing it as a provision that each has a different target. The verses on inheritance specialize the provisions of a will that are general in nature and in the inheritance verses of Surah al-Nisa verses 11-12, show some of the afrad (material) testament obligations that are general to those who inherit only. From some of the differences of opinion of scholars about the existence or absence of nasakh verses about testament and inheritance shows that the will testament has been completely abrogated by inheritance verses, therefore there is no more will to testament, however if it is done then the law is circumcision, and the verses the will testament still applies (muhkam) but is only intended for a portion of heirs who do not get an inheritance, whether the property is a lot / a little. In the end, the author does not consider this research to be final and complete. But at least the existence of this paper can open new insights for those who do not know beforehand.

\section{REFERENCES}

Abrahamov, B. (2014). Ibn Al-'Arabi And The Sufis. Anqa Publishing.

Abubakar, A. Y. (2016). Metode Istislahiah: Pemanfaatan Ilmu Pengetahuan Dalam Ushul Fiqh. Jakarta: Prenada Media Group.

Al-Jaziry, A. Al-R. (2003). Kitab Al-Fiqh ‘Ala Al-Madhahib Al-Arba'ah, Vol. 1. Beirut: Dar Al-Kutub Al'Ilmiyah.

Amir, A. N., Shuriye, A. O., \& Daoud, J. I. (2013). Muhammad Abduh's Influence In Southeast Asia. Middle-East Journal Of Scientific Research, 13, 124-138.

Az-Zuhaili, W. (1998). At-Tafsîr Al-Munîr Fi Al-'Aqîdah Wa Asy-Syarî’ah Wa Al-Manhaj. Damaskus: Dar Al-Fikr.

Azwar, Z. (2015). Pemikiran Ushul Fikih Al-Ghazâlî Tentang Al-Maslahah Al-Mursalah (Studi Eksplorasi Terhadap Kitab Al-Mustashfâ Min 'Ilmi Al-Ushûl Karya Al-Ghazâlî). Fitrah: Jurnal Kajian Ilmu-Ilmu Keislaman, 1(1), 47-70.

Dirjen Pembinaan Kelembagaan Agama Islam. (1998). Analisa Hukum Islam Bidang Wasiat. Jakarta: Departemen Agama.

Fatki, R. M. (2012). Dominasi Paradigma Fikih Dalam Periwayatan Dan Kodifikasi Hadis. Ahkam: Jurnal Ilmu Syariah, 12(2).

Khalid, M. R. (2015). Al Bahr Al-Muhîth: Tafsir Bercorak Nahwu Karya Abu Hayyân Al-Andalusî. Jurnal Adabiyah, 15(2), 181-192.

Mudawam, S. (2012). Syari'ah-Fiqih-Hukum Islam: Studi Tentang Konstruksi Pemikiran Kontemporer. Asy-Syir'ah: Jurnal Ilmu Syari'ah Dan Hukum, 46(2).

Salenda, K. (2017). Implikasi Hukum Surah Al-Fatihah Dalam Jami'al-Bayan'an Ta'wil Ayy Al-Qur'an Karya Ibn Jarir Al-Thabariy.

Sugiyono, P. (2011). Metodologi Penelitian Kuantitatif Kualitatif Dan R\&D. Alpabeta, Bandung.

Sunarsa, S. (2018). Hadits Topikal Tentang Wasiat Kepada Ahli Warits. Jurnal Naratas, 1(1), 1-7. 